\title{
Energy Investment Potential and Strategic Layout in Countries along the "Belt and Road" Based on Principal Component Analysis
}

\author{
Xiao-Feng Xu $\mathbb{D}^{1},{ }^{1}$ Min Liu $\mathbb{D}^{1},{ }^{1} \mathrm{Li} \mathrm{Ma},{ }^{2}$ and Yang $\mathrm{Li}^{3}$ \\ ${ }^{1}$ School of Economics and Management, China University of Petroleum (East China), Qingdao 266580, China \\ ${ }^{2}$ State Grid Energy Research Institute Co., Ltd., Beijing 102209, China \\ ${ }^{3}$ State Grid International Co-operation Division, Beijing 100031, China
}

Correspondence should be addressed to Xiao-Feng Xu; xuxiaofeng@upc.edu.cn

Received 8 February 2021; Revised 13 March 2021; Accepted 5 April 2021; Published 15 April 2021

Academic Editor: Wei Zhang

Copyright $(92021$ Xiao-Feng Xu et al. This is an open access article distributed under the Creative Commons Attribution License, which permits unrestricted use, distribution, and reproduction in any medium, provided the original work is properly cited.

It is important for energy enterprises to research on the investment potential of the energy markets in countries along the "Belt and Road," which can help them optimize the regional investment structure, reduce investment risks, and conform to the development trend of "going global." Therefore, we construct an investment potential assessment system of 29 indexes including five dimensions: politics, economy, society, energy, and cooperation and assess energy investment potential of 48 sample countries along the "Belt and Road" using principal component analysis to provide reference meanings for energy enterprises. The results show that the assessment results of investment potential are affected by a combination of multiple indexes. In addition, compared with Central Asia and South Asia, which have weak economic foundations and greater political and legal risks, the investment potential of Central and Eastern Europe and some emerging economies in Southeast Asia is higher.

\section{Introduction}

With the deepening implementation of the Belt and Road Initiative (BRI), China has made substantial investment in energy projects in BRI regions [1]. Many Chinese energy enterprises such as State Grid Corporation, China Southern Power Grid Corporation, and Power Construction Corporation have made direct investments in BRI countries by controlling interest and constructing greenfield projects. According to statistics from China Global Investment Tracker compiled by American Enterprise Institute, China invested 39.7 billion in the energy industry of countries along the "Belt and Road" in 2019, accounting for $38.36 \%$ of the total investment. Furthermore, direct investment in energy projects has long been regarded as one of the most complex international corporate activities. On the one hand, energy projects with long cycle, high cost, and wide influence range are extremely susceptible to many factors such as the host country's political environment and social environment. On the other hand, because of the different national conditions in different BRI countries, it is difficult to access their investment prospects. In contrast to the importance and complexity of energy investment, there are still few articles on the analysis of investment prospects in the energy market. Therefore, before outward direct investment in BRI countries, energy enterprises' major task is to analyse the investment potential of each country to prevent investment risks, increase investment returns, and achieve regional economic planning $[2,3]$. In addition, the assessment of the investment potential of BRI countries is helpful for energy enterprises to sort out the location factors of the investment market, clarify target investment markets, and cope with the complex and volatile international environment, thereby exploiting international markets and enhancing international competitiveness.

The Belt and Road Initiative aims to promote the connectivity of Asian, European, and African continents and their adjacent seas, establish and strengthen partnerships among the countries along the Belt and Road, set up all-dimensional, 
multitiered, and composite connectivity networks, and realize diversified, independent, balanced, and sustainable development in these countries [4]. And, the roadmap of the Belt and Road Initiative is shown in Figure 1. BRI had already excited wide attention and became a research hotspot since the initiative was advocated in 2013 [5]. Wang confirms that China's investment cooperation with countries along the Belt and Road region had been growing amid the global economic downturn [6]. Adopting institutional theory, Chen et al. examined the effect of bilateral diplomatic activities, institutional distance, and common land borders on the selection of transport infrastructure locations [7]. Li et al. have found that technique and structural effects of China's investment have positive impact on cumulative $\mathrm{CO}_{2}$ emission reduction of $\mathrm{B} \& \mathrm{R}$ region, while the scale effect has the negative contribution [8]. Ahmad et al. found that foreign investment has two contradictory effects on the environmental quality of BRI countries: energy consumption and urbanization process pollute the environment, while trade openness improves environmental quality [9]. In fact, there are relatively few studies on energy investment compared to transport infrastructure and environmental impact assessment. Based on the above analysis, we create an assessment model of energy investment potential about BRI countries.

Direct investment in energy projects is a complex international corporate activity, which is concerned with multifaced factors including politics, economy, and society [10-13]. Therefore, the key to assess energy investment potential is to establish a scientific, comprehensive, and multidimensional system of assessment [14]. The Worldwide Governance Indicators (WGI) developed by the World Bank is one of the comprehensive indicators with great influence, high rigor, and wide usage in many current quantitative research studies on governance [15], which is often used to evaluate the effect of the political environment on investment. By comparing 49 countries along BRI with 43 countries in other regions, Buckley et al. found that China's direct investment in BRI countries is highly sensitive to exchange rate level, market potential, openness, and infrastructure facilities of host countries [16]. Fedderke and Romm divided the factors that determine foreign direct investment into policy factors and nonpolicy factors. Nonpolicy factors include market size and political and economic stability, and policy factors include openness, product-market regulation, labour market arrangements, corporate tax rates, and infrastructure [17]. The study by Fan et al. indicates that China's direct investment positively correlates with nature resource endowment of host countries [18]. $\mathrm{Wu}$ and $\mathrm{Hu}$ presented that the cooperative relationship between host countries and China has influence on investment location selection [14]. In this paper, after analysing the above indexes, we create an investment potential assessment system of 29 indexes including five dimensions: politics, economy, society, energy, and cooperation.

At present, main methods of investment environment evaluation includes stochastic frontier gravity model, network analytic hierarchy process, and principal component analysis. [19]. Armstrong introduced the stochastic frontier into the gravity model, which has a good explanatory power for international investment activities [20]. Song and Zhou used the stochastic frontier gravity model to analyse the efficiency of trade between Chinese provinces and Pakistan from 2010 to 2018 [21]. Zhao and Jia used the stochastic frontier analysis method to verify that China's import trade is related to the economic scale, population, geographical distance, and border situation of BRI countries [22]. Jiang used network analysis to compare Sudan, Iran, Iraq, and Venezuela from five dimensions: politics, economy, infrastructure, social culture, and physical geography [23]. In his study, Zhang analysed the investment facilitation level of 50 Asian, European, and African countries along the "Belt and Road" based on principal component analysis [24]. Qi and Ren used principal component analysis to study the impact of the host country's development level of digital economy on the location and scale of China's investment in the Belt and Road countries [25]. Fan et al. constructed an indicator system from the four dimensions of port efficiency, customs' environment, regulatory environment, and financial e-commerce and used principal component analysis to evaluate the trade facilitation level of the Belt and Road countries [26]. However, the stochastic frontier gravity model has weak theoretical foundations [18], and when setting inefficiency elements, due to human differences or omission of important factors, the investment potential under different indicators may vary greatly [14]. In other words, this method has defects in robustness and accuracy. Considering the complexity of the comprehensive index assessment system in this paper, principal component analysis is chosen to analyse investment potential.

Based on the above analysis, we focus on the assessment of energy investment potential and create an investment potential assessment system of 29 indexes including five dimensions: politics, economy, society, energy, and cooperation at first. Then, we assess energy investment potential of 48 sample countries using principal component analysis. Finally, we divide BRI countries into 8 major groups as Mongolia, Russia, Southeast Asia, CIS, South Asia, West Asia, North Africa, Central and Eastern Europe, and Central Asia and put forward the strategic layout to provide reference meanings for energy enterprises.

The rest of this paper is structured as follows. In Section 2 , an assessment model of energy investment potential about BRI countries is created, which consists of indexes, samples, and method. In Section 3, assessment results of 48 sample countries using principal component analysis are illustrated based on data obtained from World Bank and International Labour Organization. In Section 4, the strategic layout is proposed based on assessment results. And, corresponding conclusions and advise are put forward in Section 5.

\section{Assessment Model Design}

2.1. Model Frame Design. The paper quantitatively analyses the investment potential of energy markets in countries along the "Belt and Road" using principal component analysis. The assessment model mainly includes three important parts: index analysis module, sample analysis module, and method design module $[27,28]$, as shown in Figure 2. First, it is vital to adopt a scientific and comprehensive assessment system for the 


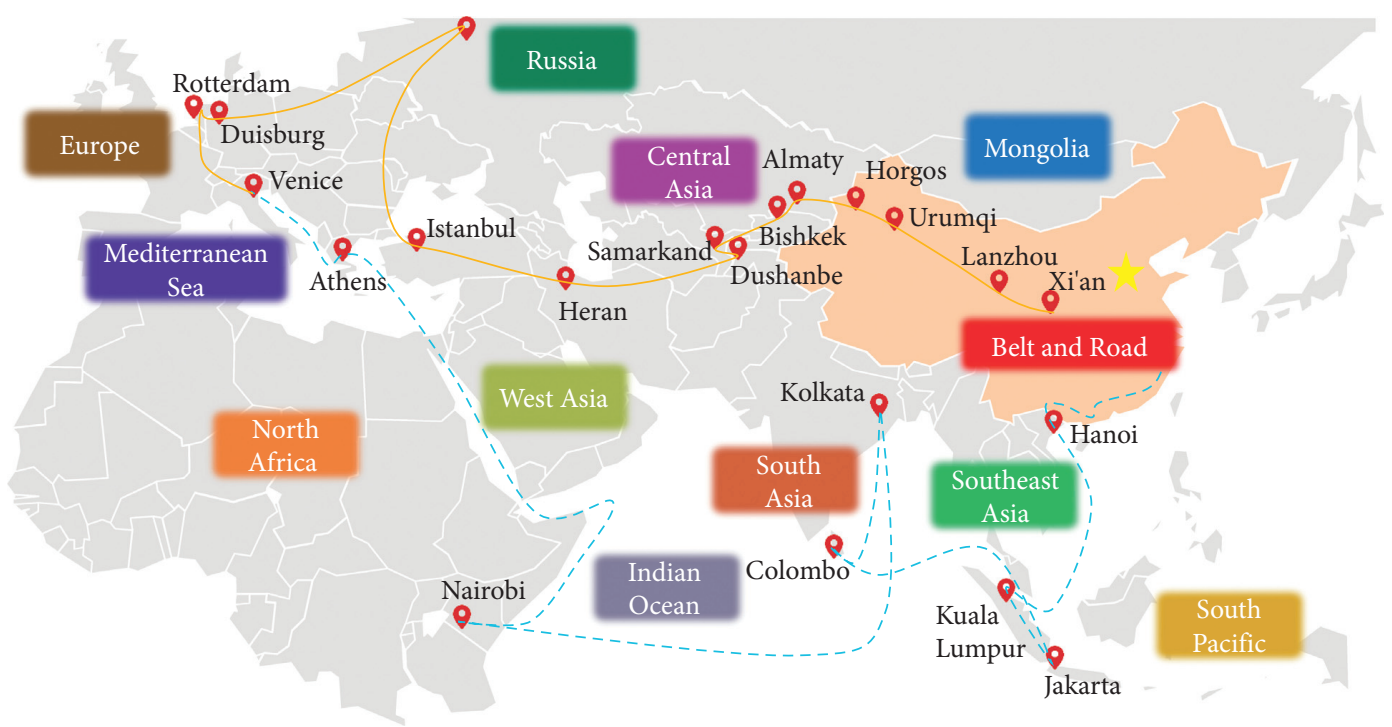

Figure 1: The Belt and Road Initiative roadmap.

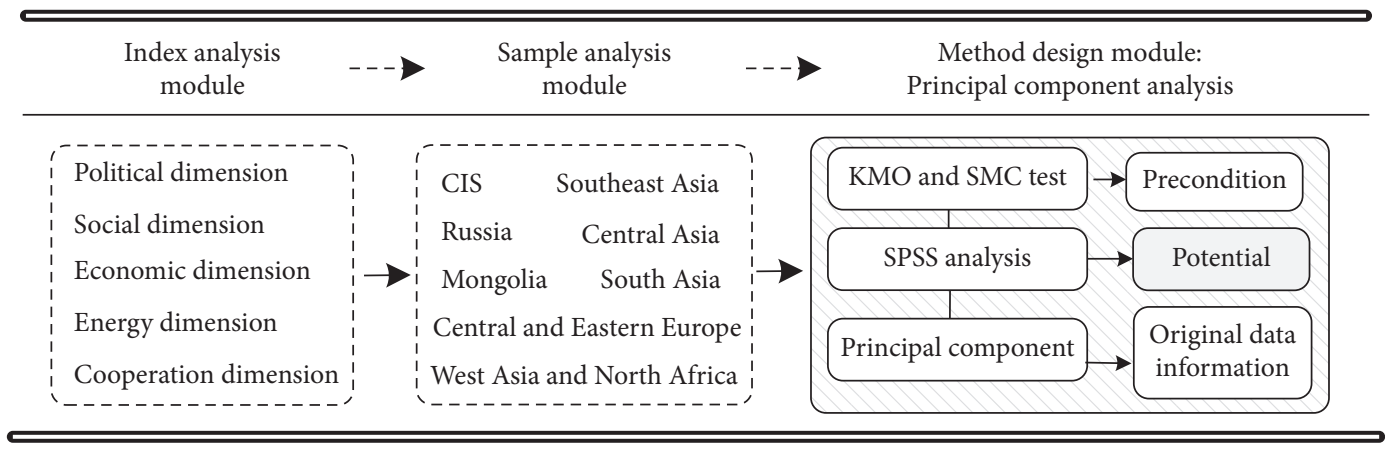

Figure 2: Model frame.

reliability of results $[29,30]$; therefore, the factors affecting the energy investment in BRI countries are classified and sorted out in the index analysis module. After that, the list and number of sample countries to be analysed are finally determined based on the official data integrity in the sample analysis module. Finally, principal component analysis is used to cope with the data, and 48 sample countries are ranked according to the assessment results in the method design module.

2.2. Index Analysis. China's energy investment potential in BRI countries is affected by many factors such as the host country's political environment, social environment, economic environment, energy environment, and cooperative relationship between the host country and China [31]. Political factors refer to indexes that measure the efficiency of government work, such as the quality of handling national issues and supervision and the effectiveness of maintaining political stability and legal construction. Energy projects require various government licenses, so political factors have a major impact on energy investment. Social factors refer to indexes that affect the investment potential due to the social conditions of the host country, including social stability, employment levels, and many other aspects. Energy companies need to coordinate various social relations in the host country, including local labour and various organizations. The host society's recognition degree of Chinese investment has a huge impact on the investment potential. Economic factors are indexes to measure the long-term stability of the host country's investment environment. Countries with a better economic environment have lower investment risks, which in turn lead to relatively higher investment profitability and security and higher investment potential. Energy factors refer to indexes such as energy resource endowment and energy cooperation with China, which measure the development prospects of the host countries' energy field and the energy cooperation potential with China. The richer the host country's energy reserves, the easier it is to attract foreign investment. The cooperative relationships between host countries and China reflect their closeness of trade and investment. The friendlier the relationships between the host countries and China, the higher the possibility of China's investment in them. The meanings and sources of 29 indexes from the above 5 dimensions are shown in Table 1 .

2.3. Sample Analysis. This paper refers to the standard of classification for BRI countries in the Political Risk Assessment Report on "Belt and Road" Energy Resources Investment compiled by National Academy of Development and Strategy 
TABLE 1: Description of indexes.

\begin{tabular}{|c|c|c|c|}
\hline Dimension & Index system & Index description & Data source \\
\hline \multirow{6}{*}{ Politics } & Control of corruption & $\begin{array}{c}\text { Reflects perceptions of the extent to which public power is exercised for } \\
\text { private gain }\end{array}$ & WGI $^{1}$ \\
\hline & Government effectiveness & $\begin{array}{l}\text { Reflects perceptions of the quality of public services, the quality of the } \\
\text { civil service, the degree of its independence from political pressures, } \\
\text { and the quality of policy formulation and implementation }\end{array}$ & WGI \\
\hline & Political stability & $\begin{array}{c}\text { Measures perceptions of the likelihood of political instability and/or } \\
\text { politically-motivated violence }\end{array}$ & WGI \\
\hline & Regulatory quality & $\begin{array}{l}\text { Reflects perceptions of the ability of the government to formulate and } \\
\text { implement sound policies and regulations that permit and promote } \\
\text { private sector development }\end{array}$ & WGI \\
\hline & Rule of law & $\begin{array}{l}\text { Reflects perceptions of the extent to which agents have confidence in } \\
\text { and abide by the rules of society }\end{array}$ & WGI \\
\hline & Voice and accountability & $\begin{array}{c}\text { Reflects perceptions of the extent to which a country's citizens are able } \\
\text { to participate in selecting their government, as well as freedom of } \\
\text { expression, freedom of association, and a free media }\end{array}$ & WGI \\
\hline \multirow{5}{*}{ Society } & Investment freedom & 1-100 points, the higher the score, the higher the investment freedom & $\mathrm{ITC}^{2}$ \\
\hline & Trade freedom & 1-100 points, the higher the score, the higher the trade freedom & ITC \\
\hline & Labour freedom & $1-100$ points, the higher the score, the higher the labour freedom & $\mathrm{IEF}^{3}$ \\
\hline & Total labour force & Total labour force of the host country & $\mathrm{ILO}^{4}$ \\
\hline & Unemployment rate & Total unemployment/total population & $\mathrm{WDI}^{5}$ \\
\hline \multirow{8}{*}{ Economics } & Electricity consumption & Electricity consumption level in host countries & $\mathrm{CE}^{6}$ \\
\hline & $\begin{array}{l}\text { Electricity consumption } \\
\text { per capita }\end{array}$ & Electricity consumption per in host countries & $\mathrm{CE}$ \\
\hline & Electricity rate & Development level of electricity infrastructure in host countries & $\mathrm{GCR}^{7}$ \\
\hline & Average GDP growth rate & Average GDP growth rate in the past three years & WDI \\
\hline & Industry's share of GDP & Gross industrial output value/GDP & WDI \\
\hline & Investment openness & Inflow of investment/GDP & WDI \\
\hline & Trade openness & $($ Total export + total import $) /$ GDP & ITC \\
\hline & Ease of doing business & $0-100$ points, the higher the score, the better the business environment & Doing business \\
\hline \multirow[b]{2}{*}{ Energy } & $\begin{array}{c}\text { Energy resource } \\
\text { endowment }\end{array}$ & Reserves of crude oil, natural gas, and coal & $\mathrm{EIA}^{8}$ \\
\hline & $\begin{array}{l}\text { Attention degree of energy } \\
\text { investment }\end{array}$ & China's energy investment/China's total investment & $\begin{array}{l}\text { China Global } \\
\text { Investment Tracker }\end{array}$ \\
\hline \multirow{4}{*}{ Cooperation } & Export dependence & Total export from China/total export & ITC \\
\hline & Import dependence & Total import from China/total import & ITC \\
\hline & Investment dependence & China's direct investment to the host country & $\begin{array}{l}\text { China Global } \\
\text { Investment Tracker }\end{array}$ \\
\hline & $\begin{array}{l}\text { Degree of nonperforming } \\
\text { investment }\end{array}$ & Nonperforming investment/total import & \\
\hline
\end{tabular}

${ }^{1}$ Worldwide Governance Indicators, ${ }^{2}$ International Trade Centre (Trade Map), ${ }^{3}$ Index of Economic Freedom, ${ }^{4}$ International Labour Organization, ${ }^{5}$ World Development Indicator, ${ }^{6}$ Country Economy, ${ }^{7}$ Global Competitive Report, and ${ }^{8}$ Energy Information Administration of United States.

and concludes the strategic layout after dividing 64 BRI countries into 8 major groups: Mongolia, Russia, Southeast Asia, CIS, South Asia, West Asia, North Africa, Central and Eastern Europe, and Central Asia (as shown in Table 2). 16 countries (marked with $i$ in Table 2) including Brunei, Iraq, and Syria have serious data missing problems due to wars and economic backwardness, so principal component analysis is used to evaluate the investment potential of other 48 countries after removing the above 16 countries.

2.4. Method Design. The comprehensive index system constructed in this paper is complex and contains many variables. It is very important to choose a suitable assess method [32-34]. The principal component analysis method can eliminate the correlation between variables and reduce the workload of calculation. In addition, the variance contribution rate of each principal component is determined according to the variance, which is relatively objective due to the elimination of human influence. Therefore, the principal component comprehensive assessment method is finally selected to analyse the investment potential. Principal component analysis is mainly used for data dimensionality reduction, and its basic thought is to maximize the projection variance of the dataset as much as possible, while reducing the dimensionality of the dataset. The data is orthogonally transformed to achieve the purpose of not only retaining most of the original data information but also removing the redundant information of the data, which is for data analysis and comparison. 
TABLE 2: BRI countries.

\begin{tabular}{|c|c|c|}
\hline Number & Regions & Countries \\
\hline 1 & Mongolia & Mongolia \\
\hline 2 & Russia & Russia \\
\hline 3 & Southeast Asia (11) & $\begin{array}{c}\text { Indonesia, Thailand, Malaysia, Vietnam, Singapore, Laos, Philippines, Cambodia, Myanma0072 } \\
\text { Brunei }^{\hat{\imath}} \text {, and East Timor }\end{array}$ \\
\hline 4 & CIS (6) & Ukraine, Belarus, Georgia, Azerbaijan, Armenia, and Moldova \\
\hline 5 & South Asia (8) & India, Pakistan, Bangladesh, Sri Lanka, Nepal, Afghanistan ${ }^{2 /}$, Maldives $^{2 /}$, and Bhutan ${ }^{2 \pi}$ \\
\hline 6 & $\begin{array}{l}\text { West Asia and North } \\
\text { Africa (16) }\end{array}$ & 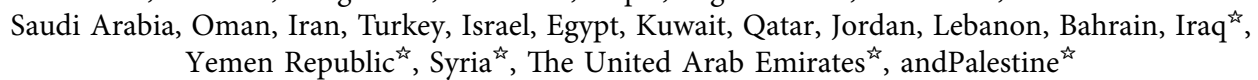 \\
\hline 7 & $\begin{array}{l}\text { Central and Eastern } \\
\text { Europe (16) }\end{array}$ & $\begin{array}{c}\text { Poland, Romania, Czech Republic, Slovakia, Bulgaria, Hungary, Latvia, Lithuania, Slovenia, Estonia, } \\
\text { Croatia, Albania, Serbia, Macedonia }{ }^{\sqrt[4]{4}} \text {, Bosnia and Herzegovina }{ }^{\sqrt{4}} \text {, and Montenegro }\end{array}$ \\
\hline 8 & Central Asia (5) & Kazakhstan, Kyrgyzstan, Tajikistan, Uzbekistan ${ }^{\not 2}$, and Turkmenistan ${ }^{\text {出 }}$ \\
\hline
\end{tabular}

In order to analyse and evaluate the investment potential index system of 48 BRI countries, this paper chooses principal component analysis to reduce the data dimension, calculates the synthesis score of each sample, and then rank and compare the samples. The basic steps of principal component analysis are as follows:

(1) Construct a data matrix of $48 \times 29$. The assessment model contains 48 samples, and each sample contains 29 indexes, so the paper constructs a data matrix $X=\left(x_{i, j}\right)_{48 \times 29}$ :

$$
X=\left\{\begin{array}{l}
x_{1,1}, x_{1,2} \ldots x_{1,29}, \\
\ldots \ldots \\
x_{48,1}, x_{48,2} \ldots x_{48,29} .
\end{array}\right.
$$

(2) Make dimensionless and standardized processing. In order to eliminate the influence of dimension and order of magnitude between indexes, the paper makes dimensionless and standardized processing of the data and obtains the matrix $Y=\left(y_{i, j}\right)_{48 \times 29}$.

(3) Construct the correlation coefficient matrix. The correlation coefficient reflects the correlation relation between standardized data:

$$
R=\left\{\begin{array}{l}
r_{1,1}, r_{1,2} \ldots r_{1,29} \\
\ldots \\
r_{48,1}, r_{48,2} \ldots r_{48,29}
\end{array}\right.
$$

where $r_{i, j}$ represents the correlation coefficient between the index $i$ and index $j$. And, its calculation formula is as follows:

$$
r_{i, j}=\frac{\sum_{k=1}^{48}\left(y_{k, i}-\overline{y_{i}}\right)\left(y_{k, j}-\overline{y_{j}}\right)}{\sqrt{\sum_{k=1}^{48}\left(y_{k, i}-\overline{y_{i}}\right)^{2} \sum_{k=1}^{48}\left(y_{k, j}-\overline{y_{j}}\right)^{2}}} .
$$

(4) Calculate eigenvalues and eigenvectors of the correlation coefficient matrix. The paper obtains eigenvalue $\lambda_{i}(i=1,2, \ldots, 29)$ according to the characteristic equation $|R-\lambda E|=0$ and then gets the eigenvectors based on the equation $R \mu_{i}=\lambda_{i} \mu_{i}$.

(5) Select principal components. This paper sorts the principal components $F_{1}, F_{2}, \ldots F_{48}$ according to the value of eigenvalues and then calculates variance contribution rate and cumulative variance contribution rate of each principal component. The top $p$ principal components with a cumulative contribution rate greater than $80 \%$ are selected to ensure that they can basically express the information in the original data:

$$
\left\{\begin{array}{l}
F_{1}=\mu_{1,1} y_{1}+\mu_{1,2} y_{2}+\ldots+\mu_{1,29} y_{29} \\
\ldots \quad \ldots \\
F_{48}=\mu_{48,1} y_{1}+\mu_{48,2} y_{2}+\ldots+\mu_{48,29} y_{29}
\end{array}\right.
$$

where the variance contribution rate of the $i$ th principal component can be expressed as $\alpha_{i}=\lambda_{i} / \sum_{i=1}^{p} \lambda_{i}$ and variance contribution rate can be expressed as $G(k)=\sum_{i=1}^{k} \lambda_{i} / \sum_{i=1}^{p} \lambda_{i}$.

(6) Calculate the synthesis score.

\section{Result Analysis and Strategic Layout}

Before the principal component analysis, the paper first conducts the KMO test and SMC test on the investment potential index system to verify the correlation between the 29 subindicators and judge whether the data is suitable for this method. The higher the value of the KMO test and SMC test, the stronger the linear relationship and commonality between the subindicators and the more reliable the results of principal component analysis. Generally speaking, only when the KMO test result is greater than 0.5 and the SMC test result is less than 0.05 , the index system is suitable for principal component analysis. It can be seen from Table 3 that the results of principal component analysis based on the investment potential index system of BRI countries are meaningful.

The paper uses SPSS 23.0 to process data from countries along the "Belt and Road." As shown in Table 4, the cumulative variance contribution rate of the first nine principal components is as high as $81.134 \%$. In other words, the first nine principal components obtained after principal component analysis can express more than $80 \%$ of the original information which can then accurately evaluate the investment potential of the host country. The paper uses the range method to standardize the results of the principal 
TABLE 3: Results of the KMO and SMC test.

\begin{tabular}{lll}
\hline KMO measure of sampling adequacy & & 0.577 \\
& Chi-square & 1150.232 \\
Bartlett test of sphericity & Degree of freedom & 406 \\
& Significance & 0.000 \\
\hline
\end{tabular}

TABLE 4: Variance contribution rate and cumulative variance contribution rate of principal components.

\begin{tabular}{|c|c|c|c|}
\hline Component number & Eigenvalue & Variance contribution rate & Cumulative \\
\hline 1 & 7.608 & 26.234 & 26.234 \\
\hline 2 & 3.534 & 12.186 & 38.421 \\
\hline 3 & 2.919 & 10.066 & 48.486 \\
\hline 4 & 2.688 & 9.268 & 57.754 \\
\hline 5 & 2.301 & 7.936 & 65.690 \\
\hline 6 & 1.398 & 4.821 & 70.511 \\
\hline 7 & 1.228 & 4.234 & 74.745 \\
\hline 8 & 0.970 & 3.346 & 78.091 \\
\hline 9 & 0.883 & 3.044 & 81.134 \\
\hline 10 & 0.780 & 2.690 & 83.824 \\
\hline 11 & 0.736 & 2.537 & 86.361 \\
\hline 12 & 0.660 & 2.275 & 88.636 \\
\hline 13 & 0.527 & 1.818 & 90.454 \\
\hline 14 & 0.458 & 1.580 & 92.034 \\
\hline 15 & 0.419 & 1.445 & 93.479 \\
\hline 16 & 0.365 & 1.258 & 94.737 \\
\hline 17 & 0.285 & 0.982 & 95.719 \\
\hline 18 & 0.278 & 0.960 & 96.679 \\
\hline 19 & 0.203 & 0.701 & 97.380 \\
\hline 20 & 0.181 & 0.625 & 98.006 \\
\hline 21 & 0.154 & 0.532 & 98.538 \\
\hline 22 & 0.125 & 0.431 & 98.969 \\
\hline 23 & 0.091 & 0.315 & 99.284 \\
\hline 24 & 0.059 & 0.205 & 99.489 \\
\hline 25 & 0.057 & 0.195 & 99.685 \\
\hline 26 & 0.042 & 0.144 & 99.829 \\
\hline 27 & 0.027 & 0.092 & 99.921 \\
\hline 28 & 0.016 & 0.057 & 99.978 \\
\hline 29 & 0.006 & 0.022 & 100.000 \\
\hline
\end{tabular}

component analysis, obtains the final evaluation results, and ranks the sample countries.

From the perspective of overall investment potential assessment results, there is an obvious difference in energy investment potential between 48 BRI countries: 12 countries' investment potential values are above $0.5,15$ countries' values are between 0.3 and 0.5 , and 21 countries' values are below 0.3. Analysing Table 5, it can be found that Central and Eastern European countries and some Southeast Asian countries with great economic level are ranked higher in investment potential, and Central and South Asian countries with poor economic development and weak infrastructure are ranked lower.

From the perspective of regional evaluation results, the regions with the highest investment potential are Central and Eastern Europe, and the lowest are Central Asia and South Asia. The average value of investment potential in each region is shown in Figure 3. The stable political environment and perfect legal system in Central and Eastern Europe facilitate the inflow of foreign capital, so the investment potential of countries in this region is generally high. In South Asia, India's high investment potential benefits from the vast energy market, and the generally low investment potential of other countries is caused by high political and legal risks. In Central Asia, Kazakhstan's higher investment potential is due to strategic resource factors. In Southeast Asia, the high investment potential of Singapore and Malaysia is mainly due to the large economy and high energy demand. The investment potential of West Asia and North Africa countries is generally in the middle.

\section{Strategic Layout}

Aiming at the investment potential evaluation results of 48 BRI countries, energy enterprises should tend to invest in countries with greater investment potential and reduce investment in countries with less investment potential to reduce nonperforming investment, increase the rate of return on funds, expand overseas markets, and enhance international competitiveness. The strategic layout is 
TABLE 5: Ranking of BRI countries.

\begin{tabular}{|c|c|c|}
\hline Country & Score & Ranking \\
\hline Singapore & 1.000 & 1 \\
\hline Estonia & 0.731 & 2 \\
\hline Czech & 0.662 & 3 \\
\hline Slovenia & 0.652 & 4 \\
\hline Slovakia & 0.622 & 5 \\
\hline Latvia & 0.621 & 6 \\
\hline Lithuania & 0.598 & 7 \\
\hline Israel & 0.597 & 8 \\
\hline Hungary & 0.593 & 9 \\
\hline Malaysia & 0.570 & 10 \\
\hline Georgia & 0.565 & 11 \\
\hline Poland & 0.553 & 12 \\
\hline India & 0.483 & 13 \\
\hline Bahrain & 0.476 & 14 \\
\hline Qatar & 0.467 & 15 \\
\hline Oman & 0.459 & 16 \\
\hline Croatia & 0.450 & 17 \\
\hline Bulgaria & 0.447 & 18 \\
\hline Romania & 0.421 & 19 \\
\hline Kuwait & 0.415 & 20 \\
\hline Russia & 0.384 & 21 \\
\hline Jordan & 0.362 & 22 \\
\hline Turkey & 0.358 & 23 \\
\hline Serbia & 0.354 & 24 \\
\hline Thailand & 0.335 & 25 \\
\hline Albania & 0.317 & 26 \\
\hline Armenia & 0.316 & 27 \\
\hline Saudi Arabia & 0.293 & 28 \\
\hline Vietnam & 0.260 & 29 \\
\hline Sri Lanka & 0.255 & 30 \\
\hline Kazakhstan & 0.244 & 31 \\
\hline Moldova & 0.238 & 32 \\
\hline Mongolia & 0.228 & 33 \\
\hline Philippines & 0.224 & 34 \\
\hline Indonesia & 0.210 & 35 \\
\hline Kyrgyzstan & 0.178 & 36 \\
\hline Egypt & 0.177 & 37 \\
\hline Ukraine & 0.164 & 38 \\
\hline Azerbaijan & 0.156 & 39 \\
\hline Lebanon & 0.141 & 40 \\
\hline Belarus & 0.126 & 41 \\
\hline Nepal & 0.080 & 42 \\
\hline Iran & 0.043 & 43 \\
\hline Tajikistan & 0.026 & 44 \\
\hline Cambodia & 0.010 & 45 \\
\hline Pakistan & 0.009 & 46 \\
\hline Laos & 0.009 & 47 \\
\hline Bangladesh & 0.000 & 48 \\
\hline
\end{tabular}

concluded after dividing 64 BRI countries into 8 major groups as Mongolia, Russia, Southeast Asia, CIS, South Asia, West Asia, North Africa, Central and Eastern Europe, and Central Asia in the following section.

4.1. Southeast Asia. In Southeast Asia, the investment potentials of 8 countries including Indonesia, Thailand, Malaysia, Vietnam, Singapore, Philippines, Myanmar, Cambodia, and Laos are assessed. Among the abovementioned 8 countries, Singapore ranks first, Malaysia ranks tenth, the other 6 countries are in the inferior position, and Laos ranks the worst at 47th. Compared with other Southeast Asian countries, Singapore and Malaysia's value of investment freedom, trade freedom, labour freedom, and trade openness are higher, but political risk is lower, which provides a powerful explanation for the evaluation results. From the aspect of Cambodia and Laos, the promotion of friendly relations with China has attracted a large amount of government capital inflow. However, these two countries have small territories, high political and legal risks, poor economic development, and low labour quality, which makes their future investment potentials small. Energy enterprises should formulate preventive measures in response to the above situations to avoid unnecessary losses.

4.2. Commonwealth of Independent States. The investment potentials of 6 CIS countries including Ukraine, Belarus, Georgia, Azerbaijan, Armenia, and Moldova are evaluated. Among the 6 countries, Georgia ranks the highest at 11th, and Ukraine, Azerbaijan, and Belarus rank the worst at 38th, 39th, and 41st, respectively. Like Singapore and Malaysia, Georgia's value of investment freedom, trade freedom, labour freedom, and trade openness are higher, but political risk is lower. In addition, Georgia has rich coal reserves. Russia's scores of corruption control, government effectiveness, political stability, regulatory quality, law rule, voice, and accountability are generally low, which shows that it has a high political risk. And, the high political risk is a major obstructive factor to capital inflows due to large-scale and irreversible characteristics of energy investment. Therefore, energy enterprises can first choose Georgia when they want to invest in the CIS countries.

4.3. South Asia. In South Asia, the investment potentials of 5 countries including India, Pakistan, Bangladesh, Sri Lanka, and Nepal are evaluated. Among them, India ranks the highest at 13th place, Sri Lanka ranks 30th, and the other three countries in the inferior position. The score of India's investment potential is close to 0.5 , and the major indexes contributing much to it are market size, labour force, and coal reserves. However, due to the prevalence of "national protectionism" and the hindrance of the "national security investigation policy" in India [14], there is still greater uncertainty about whether energy enterprises can invest in India in the future. The indicators leading to the poor ranking of Pakistan, Bangladesh, and Nepal mainly include market size, investment freedom, trade freedom, labour freedom, and trade openness.

4.4. West Asia and North Africa. In West Asia and North Africa, the investment potentials of 11 countries including Saudi Arabia, Oman, Iran, Turkey, Israel, Egypt, Kuwait, Qatar, Jordan, Lebanon, and Bahrain are assessed. The investment potential scores of the countries in West Asia are relatively even; apart from Israel ranking 8 th, most of which are ranked between 10 and 30 . Therefore, energy companies can choose investment countries based on strategic needs. It 


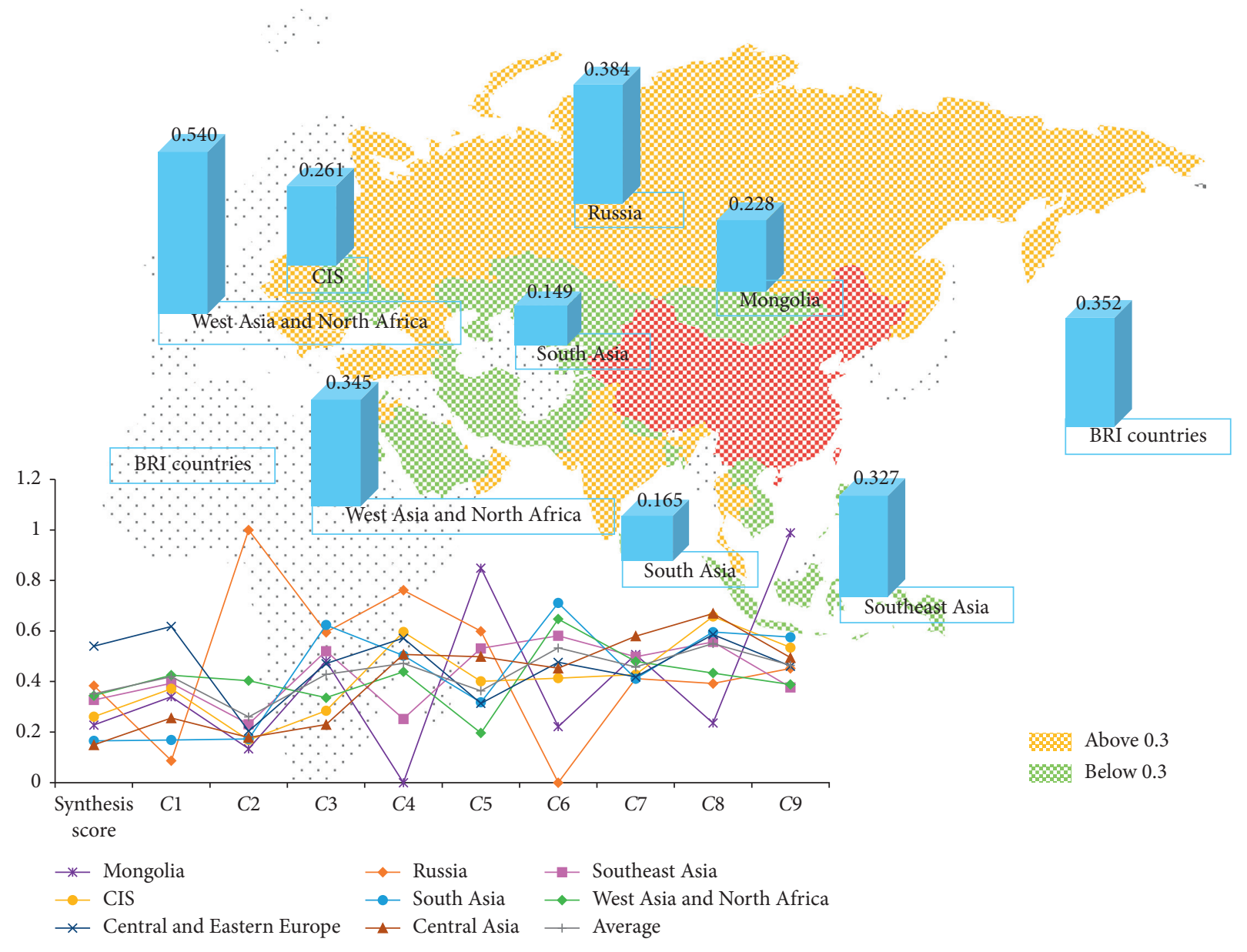

FIGURE 3: Regional assessment results of BRI.

should be noted that since West Asia and North Africa are important international oil-producing regions, trade competition and war risks are relatively high, and energy companies should formulate comprehensive risk control measures to ensure the efficiency of investment.

4.5. Central and Eastern Europe. In Central and Eastern Europe, the investment potentials of 13 countries including Poland, Romania, Czech Republic, Slovakia, Bulgaria, Hungary, Latvia, Lithuania, Slovenia, Estonia, Croatia, Albania, and Serbia are evaluated. Central and Eastern Europe is the region with the highest investment potential; except for Albania and Serbia, other countries are all ranked above the 20th. Central and Eastern European countries have the most complete political and legal systems and the highest degree of investment openness and trade freedom, which determine the much higher investment potential.

4.6. Central Asia. In Central Asia, the investment potentials of 3 countries including Kazakhstan, Kyrgyzstan, and Tajikistan are assessed due to serious data missing problems of Uzbekistan and Turkmenistan. And, the average investment potential scores of these three countries are poor, ranking 31st, 36th, and 44th, respectively. China and countries in Central Asia are joined by common mountains and rivers, and the friendly relationship between them drives the inflow of Chinese capital. However, the future investment potentials of Central Asian countries are limited by their basic national conditions, such as low labour quality, poor economic level, and backward infrastructure.

4.7. Russia and Mongolia. Russia and Mongolia are, respectively, 21 st and $33 \mathrm{rd}$ in the investment potential assessment results. They are both adjacent to China and have abundant reserves of natural resources. However, compared with Mongolia, Russia has a broader energy market and a lower degree of nonperforming investment, so Russia's investment potential is relatively high. In addition, the omnidirectional, multidomain, and multilevel strategic cooperation between Russia and China will drive Chinese capital to flow into Russia.

\section{Summary}

For one thing, we construct an investment potential assessment system of 29 indexes including five dimensions: politics, economy, society, energy, and cooperation in this paper and then assess energy investment potential of 48 sample countries along the "Belt and Road" using principal 
component analysis. Finally, we propose the strategic layout, and we wish it can contribute reference to energy enterprises. Through empirical analysis, the following conclusions are concluded: (1) assessment results of investment potential are affected by a combination of multiple indexes, and different indexes contribute differently to assessment results. For example, political factors made more contribution to investment potential assessment results of Central and Eastern European countries, while economic factors made more contribution to India. (2) Energy investment potential measures the future investment value of the host country's energy field. By analysing the evaluation results, compared with Central Asia and South Asia which have weak economic foundations and greater political and legal risks, the investment potential of Central and Eastern Europe and some emerging economies in Southeast Asia is higher.

Aiming at the above conclusion, relevant suggestions are put forward in this section. First, before entering the overseas market, energy enterprises must actively conduct market research and have a full and thorough understanding of investment and financing projects. At the same time, it is also necessary to keep abreast of changes in the host country's policies and laws in order to effectively avoid overseas investment risks. Second, energy enterprises should clarify target investment markets, increase capital utilization, and focus on investing in countries with greater potential to avoid risky investment and reduce bad investment. Third, energy enterprises should improve the risk control system. It can be found that different countries along BRI face different risks by analysing the constructed assessment index system. Accordingly, energy enterprises should gradually establish risk database and formulate operable strategies of risk identification, risk analysis, risk evaluation, risk response, and risk supervision. Fourth, energy enterprises should actively broaden investment and financing channels. Energy projects have long investment cycles and high uncertainty; consequently, energy enterprises should flexibly use a variety of investment ways to improve the return on investment in accordance with the development stage and profitability of the project. Fifth, energy enterprises should choose investment strategies according to circumstances and conditions. Energy enterprises can choose various investment methods based on market characteristics and potential. For example, the investment method of obtaining partial equity is adopted in Central and Eastern Europe which has complete legal system and less cooperation with China, while the method of obtaining franchise rights is adopted in the emerging economies with broad market prospects and cooperation experience. Finally, energy enterprises must implement China's "Going Global" strategy, the "Belt and Road" initiative, and other policy recommendations. Energy enterprises should make full use of intergovernmental economic diplomacy, give full play to the advantages of China's power industry in financing and technology within the framework of diplomacy, and continuously expand the target market for China's power industry and technical standards.

\section{Data Availability}

The datasets generated and analysed during the current study are available from the corresponding author upon reasonable request.

\section{Conflicts of Interest}

The authors declare that they have no conflicts of interest.

\section{Acknowledgments}

This research was supported by State Grid Corporation of China Headquarter Technology Project.

\section{References}

[1] J. Du and Y. Zhang, "Does one belt one road initiative promote Chinese overseas direct investment?" China Economic Review, vol. 47, pp. 189-205, 2018.

[2] C.-L. Wang, L. Li, and X.-F. Xu, "Decision model for "going global" of China's electric power technology and equipment," Procedia Computer Science, vol. 162, pp. 623-627, 2019.

[3] M. Jiang, G. Gao, Y. Deng, and C. Wang, "Market risks prevention and control of "going global" for Chinese electrical enterprises," Procedia Computer Science, vol. 162, pp. 15-18, 2019.

[4] J. Liu, "Development of regional logistics along the one belt and one road," 2016.

[5] W. J. Jixian and Y. Selina, "Case studies on transport infrastructure projects in belt and road initiative: an actor network theory perspective," Journal of Transport Geography, vol. 71, pp. 213-223, 2018.

[6] L. Wang, "Trade and investment along the belt and road region soar amid global economic downturn," China's Foreign Trade, vol. 3, pp. 34-35, 2020.

[7] Y. Chen, Y. Chao, W. Liu, K. Tao, and P. Lian, "Make friends, not money: how Chinese enterprises select transport infrastructure investment locations along the belt and road initiative," Transport Policy, vol. 101, 2020.

[8] X. Li, C. Liu, F. Wang, Q. Ge, and Z. Hao, "The effect of Chinese investment on reducing $\mathrm{CO} 2$ emission for the Belt and Road countries - science Direct," Journal of Cleaner Production, vol. 288, Article ID 125125, 2020.

[9] M. Ahmad, P. Jiang, A. Majeed, and M. Y. Raza, "Does financial development and foreign direct investment improve environmental quality? evidence from belt and road countries," Environmental Science and Pollution Research, vol. 27, 2020.

[10] A. Hashemizadeh, Y. Ju, S. M. H. Bamakan, and H. P. Le, "Renewable energy investment risk assessment in belt and road initiative countries under uncertainty conditions-ScienceDirect," Energy, vol. 214, 2020.

[11] L. Chang, J. Li, K.-C. Cheong, and L.-T. Goh, "Can existing theories explain China's outward foreign direct investment in belt and road countries," Sustainability, vol. 13, no. 3, p. 1389, 2021.

[12] L. Qian, F. Guohua, Y. Jian, Y. Min, and L. Chengxuan, "Country evaluation for China's hydropower investment in the belt and road initiative nations," Sustainability, vol. 12, 2020.

[13] X. Fangming and Z. Bing, "Impact of China's outward foreign direct investment on green total factor productivity in "belt and road" participating countries: a perspective of 
institutional distance," Environmental Science and Pollution Research, vol. 28, 2020.

[14] H. Wu and Q. Hu, "A study on the efficiency and potential of China's OFDI in countries along the belt and road route: also on the choice of investment location," Journal of Jiangxi University of Finance and Economics, vol. 206, pp. 25-37, 2020.

[15] D. Kaufmann and A. Kraay, "Governance indicators: where are we, where should we be going?" Policy Research Working Paper Series, vol. 23, no. 45, pp. 1-45, 2007.

[16] P. J. Buckley, L. J. Clegg, A. Cross, X. Liu, H. Voss, and P. Zheng, "The determinants of Chinese outward foreign direct investment," Journal of International Business Studies, vol. 38, pp. 499-518, 2007.

[17] J. W. Fedderke and A. T. Romm, "Growth impact and determinants of foreign direct investment into South Africa, 1956-2003," Economic Modelling, vol. 23, no. 5, pp. 738-760, 2006.

[18] Z. Fan, R. Zhang, X. Liu, and L. Pan, "China's outward FDI efficiency along the Belt and Road," China Agricultural Economic Review, vol. 8, no. 3, pp. 455-479, 2016.

[19] Z. Siming and Z. Mingxia, "The measure and evaluation of investment facilitation of "belt \& road" countries and China's outward foreign direct investment," The Theory and Practice of Finance and Economics, vol. 40, pp. 54-60, 2019.

[20] S. Armstrong, "Assessing the scale and potential of Chinese investment overseas: an econometric approach," China \& World Economy, vol. 19, no. 4, pp. 22-37, 2011.

[21] Z. Song and Q. Zhu, "Development of trade between China's provinces and Pakistan and influencing factors under the background of the Belt and Road Initiative," Progress in Geography, vol. 39, no. 11, pp. 1785-1797, 2020.

[22] D. Zhao and X. Jia, "An analysis of import trade pattern and development potential between China and the countries along the "belt and road"' Commercial Research, vol. 8, pp. 52-59, 2020.

[23] H. Jiang, "China's outward foreign direct investment environment evaluation model of anp and its application," Journal of UESTC (Social Sciences Edition), vol. 12, pp. 32-35, 2010.

[24] Y. Zhang, "The investment facilitation of "one belt one road" and choices of China's foreign direct investment-empirical analysis based on cross-panel data and investment gravity model," Journal of International Trade, vol. 7, pp. 165-176, 2016.

[25] J. Qi and Y. Ren, “The development level of host country's digital economy and China's outward foreign direct investment: a study of 43 countries along the belt and road," International Economics and Trade Research, vol. 36, pp. 55-71, 2020.

[26] Q. Fan, M. Wang, and S. Li, "Study on the impact of trade facilitation level of countries in "the belt and road initiatives" on China's export trade," Journal of Industrial Technological Economic, vol. 38, pp. 20-31, 2019.

[27] X. Xu, W. Zhang, N. Li, and H. Xu, "A bi-level programming model of resource matching for collaborative logistics network in supply uncertainty environment," Journal of the Franklin Institute, vol. 352, no. 9, pp. 3873-3884, 2015.

[28] X. Xu, J. Hao, L. Yu, and Y. Deng, "Fuzzy optimal allocation model for task-resource assignment problem in a collaborative logistics network," IEEE Transactions onFuzzy Systems, vol. 27, no. 5, pp. 1112-1125, 2018.

[29] Y. Su and X. L. An, "Application of threshold regression analysis to study the impact of regional technological innovation level on sustainable development," Renewable \& Sustainable Energy Reviews, vol. 89, pp. 27-32, 2018.

[30] Y. Su and Y. Yu, "Spatial agglomeration of new energy industries on the performance of regional pollution control through spatial econometric analysis," Science of The Total Environment, vol. 704, Article ID 135261, 2020.

[31] X. Xu, "Global renewable energy development: influencing factors, trend predictions and countermeasures," Resources Policy, vol. 63, 2019.

[32] X. Xu, Z. Lin, and J. Zhu, "DVRP with limited supply and variable neighborhood region in refined oil distribution," Annals of Operations Research, vol. 157, pp. 1-25, 2020.

[33] X. Xu, J. Hao, and Y. Zheng, "Multi-objective artificial bee colony algorithm for multi-stage resource leveling problem in sharing logistics network," Computers \& Industrial Engineering, vol. 142, Article ID 106338, 2020.

[34] X. Xu, Z. Lin, X. Li, C. Shang, and Q. Shen, "Multi-objective robust optimisation model for MDVRPLS in refined oil distribution," International Journal of Production Research, vol. 30, p. 1, 2021. 